Pakistan Journal of Nutrition 12 (6): 529-533, 2013

ISSN 1680-5194

(C) Asian Network for Scientific Information, 2013

\title{
Assessment of Silage Quality and Forage Acceptability of Vetiver Grass (Chrysopogon zizanioides L. Roberty) Ensiled with Cassava Peels by Wad Goat
}

\author{
O.O. Falola ${ }^{1}$, M.C. Alasa ${ }^{2}$ and O.J. Babayemi ${ }^{3}$ \\ ${ }^{1}$ Federal College of Animal Health and Production Technology, Ibadan, Nigeria \\ ${ }^{2}$ Federal College of Education (Special), Oyo, Nigeria \\ ${ }^{3}$ Department of Animal Science, University of Ibadan, Ibadan, Nigeria
}

\begin{abstract}
Vetiver grass was harvested at 4,6 and 8-week regrowth and were ensiled with cassava peels at ratio $60: 40$ and $100 \%$ without cassava peels. The quality and chemical composition of the silages were assessed. The silages along with fresh unensiled re-growths of vetiver grass were fed to WAD goats in a cafeteria method to determine the coefficient of preference of the diets. Results showed that ensiling reduced both the crude protein and crude fiber contents. Ensiling with cassava peels improved the quality and acceptability of the silage while ensiled grasses without cassava peels had poor silage quality and rejection by the animals.
\end{abstract}

Key words: Vetiver grass, silage quality, chemical composition, coefficient of preference, goats

\section{INTRODUCTION}

Ruminants in the tropics are raised predominantly on grasses which are inherently poor in digestibility, nutritive value and unavailable in the off season (Babayemi, 2009). The shortage of good quality forage needed to sustain livestock growth especially during the dry season has been a perennial problem in Nigeria. The native pasture deteriorate rapidly especially in the dry season, hence the need for conservation in form of silage which is not weather dependent like hay, during the rainy season; when they are in abundant supply and high in nutritive value. Free choice intake and acceptability study is a quick assessment of physical quality of a feed. Coefficient of Preference (CoP) is a direct measure of acceptability and nutritional capability of feedstuff or forage. In recent times cafeteria technique have been used to assess the acceptability of some forages (Bamikole et al., 2004; Babayemi et al., 2006). The feed intake or the palatability of forage is regulated by many factors: harvesting, physical and metabolic feedback and secondary metabolites. Preservation method may affect these factors, especially in reducing the secondary compounds or anti-nutritional substances. In the tropical humid region, high humidity in the atmosphere and more rains in the production period limit the time of making hay and ensiling is considered to be the most promising preservation technique. Ensiling is a potent general method of forage preservation and also a form of treatment to occasionally salvage the under-utilized pasture for better acceptability and degradability. In recent year vetiver has been widely known for its effectiveness in erosion and sediment control and has also been found to be highly tolerant to extreme soil conditions (Truong and Baker, 1998).
Vetiver grass may also be a promising feed resource because of its various advantages such as high quality, fast growth rate and easy adaptation to the environment and can bear repetitive mowing without occupying farm land. Vetiver grass was also reported to be edible herbage of high quality for cattle and goats particularly in the growing stage (Liu et al., 2003). However, so far, little is known on the application of vetiver grass as feed for ruminants.

\section{MATERIALS AND METHODS}

Silage making: Vetiver grass was harvested manually at 4,6 and 8 week old re-growth The harvested grasses at 4,6 and 8 weeks of re-growth were chopped and wilted for 12 hours in order to reduce the moisture content. The grasses were chopped into $2-3 \mathrm{~cm}$ length for ease of compaction and consolidation for silage.60 \% of each harvested grasses were ensiled with $40 \%$ cassava peels. Filling and compaction was done simultaneously to eliminate inherent air. The silage was prepared in $50 \mathrm{~kg}$ polythene bags in triplicate, the polythene bags were sealed and compressed with piles of heavy sand bag in $300 \mathrm{~L}$ drums. Fermentation was done for 42 days. The treatments were: $(60 \%$ 4-week vetiver+ $40 \%$ cassava peels) $(60 \%$ 6-week vetiver+40\%, cassava peels) $(60 \%$ 8 -week vetiver+40\% cassava peels) (100\% 4-week without cassava peels) (100\% 6-week without cassava peels) (100\% 8-week without cassava peels).

\section{Experimental design \\ Completely randomized design}

Determination of silage quality: After 42 days, the fermentation was terminated and the silage was opened 
for silage quality. The assessed quality characteristics were colour, aroma, texture, $\mathrm{pH}$ and temperature according to Babayemi and Igbekoyi (2008). Immediately the silage was opened, a laboratory thermometer was inserted to determine the temperature. The $\mathrm{pH}$ of the silage was determined by adding $100 \mathrm{ml}$ of distilled water to $25 \mathrm{~g}$ of each treatment in a beaker and a $\mathrm{pH}$ meter glass electrode was inserted to determine the $\mathrm{pH}$. Colour assessment was ascertained using visual observation with the aid of colour charts. The aroma of the silage was relatively assessed as to whether nice, pleasant, fruity or pungent. Sub-samples from different points and depths were taken and mixed together for dry matter determination by oven drying at $65^{\circ} \mathrm{C}$ until a constant weight was achieved. The samples were later milled and stored in an air-tight container until ready for chemical analysis.

Chemical and statistical analysis: Crude protein, crude fiber, ether extract and ash content of the silages were carried out in triplicates as described by AOAC (1995). The fiber components including neutral detergent fiber, acid detergent fiber and acid detergent lignin were determined according to Van Soest et al. (1991). Data were analyzed by ANOVA using the procedure of SAS (SAS, 2002). The significant means separated using Duncan (1955) multiple range F-test.

Acceptability study: The study was carried out at the sheep and goat unit of National Center for Genetic Research and Biotechnology (NACGRAB) Ibadan. Twelve adult West African Dwarf goats were used in the cafeteria feed preference study that lasted for two weeks, including the one-week of adaptation. The animals were housed in a group pen within the ruminant house which has been constructed to achieve good ventilation. Nine different feed samples offered were: A (4 week vetiver), B (6 week vetiver), C (8 week vetiver), D (60\% 4 week vetiver ensiled with $40 \%$ cassava peels), E (60\% 6week vetiver ensiled with $40 \%$ cassava peels), F (60\% 8 week vetiver ensiled with $40 \%$ cassava peels), G (100\% 4 week ensiled without cassava peels) H (100\% 6 week ensiled) and I (100\% 8week ensiled) $4 \mathrm{~kg}$ of each diet were introduced on cafeteria basis to the animals in nine different wooden feeders, thus each animal has free access to each of the diet in the trough. The positioning of the feeds was changed daily to prevent bias by the animals taking a particular part of the pen as the position for a particular type of feeds. The amount consumed was monitored for six hour per day and quantity consumed was recorded. After then the animals were released to go for grazing. Feed preference was determined from the Coefficient of Preference (CoP) value calculated from the ratio between the intakes of each individual feed sample divided by the average intake of the nine feed samples (Karbo et al., 1993; Bamikole et al., 2004). On the basis, a feed was taken to be relatively preferred if the CoP value is greater than unity:

$$
\text { CoP }=\frac{\text { Intake of individual feed offered }}{\text { Mean int ake of all the feed offered }}
$$

\section{RESULTS AND DISCUSSION}

Silage characteristics: Table 1 shows the physicochemical properties of the ensiled grasses. The 4, 6 and 8 week re-growths of vetiver grass ensiled with cassava peels were similar in their properties having olive green colour, pleasant alcoholic odour, firm texture, $\mathrm{pH}$ of 4.26 4.27 and temperature of $20^{\circ} \mathrm{C}$. While the re-growths ensiled solely without cassava peels were also similar in their properties possessing poor quality characteristics such as pungent smell, mouldy growth, $\mathrm{pH}$ of $5.56-5.66$ and temperature of $28^{\circ} \mathrm{C}$.

Good silage usually preserves the original colour of the pasture or any forage (Mannatje, 1999). The olive green colour obtained in the present study was in order. It was close to the original colour of the grass which was an indication of good quality silage that was well preserved (Oduguwa et al., 2007).

The silages with cassava peels exhibit pleasant alcoholic aroma which is an indication of well-made silage, Kung and Shaver (2002) reported that pleasant smell is accepted for good or well-made silage. The temperature of fermenting forage varying from $27-38^{\circ} \mathrm{C}$ was presumed to produce excellent silage (Muck, 1996). The temperature of silages with cassava peels were $20^{\circ} \mathrm{C}$ and lower than the range $\left(25-27^{\circ} \mathrm{C}\right)$ obtained by Babayemi (2009) in silage of Guinea grass. The temperature range appears to be the operating temperature for normal silage fermentation, good quality silage should be cooled at opening and at feed out phase having a normal room temperature (McDonald et al., 1995). Bolsen et al. (1996) reported that any excessive heat production can result in maillard or

Table 1: Physico-chemical characteristics of 4,6 and 8-week re-growths of vetiver grass silages

\begin{tabular}{lllllll}
\hline Parameters & A & B & C & D & E & F \\
\hline Colour & Olive green & Olive green & Olive green & Brownish green & Brownish green & Brownish green \\
Aroma & PA & PA & PA & Pungent & Pungent & Pungent \\
Texture & Firm & Firm & Firm & Dry/mouldy & Dry/mouldy & Dry/mouldy \\
Temperature $\left({ }^{\circ} \mathrm{C}\right)$ & 20.0 & 20.0 & 20.0 & 28.0 & 28.0 & 28.0 \\
$\mathrm{pH}$ & 4.26 & 4.26 & 4.27 & 5.57 & 5.56 & 5.66 \\
\hline A & $4.26 \%$
\end{tabular}

$\mathrm{A}=60 \%$ 4-week ensiled with $40 \%$ cassava peels, $\mathrm{B}=60 \%$-week ensiled with $40 \%$ cassava peels, $\mathrm{C}=60 \%$-week ensiled with $40 \%$ cassava peels, $D=100 \%$ 4week ensiled, $E=100 \% 6$-week ensiled, $F=100 \% 8$-week ensiled. PA: Pleasantly alcoholic 
browning reaction which can reduce the digestibility of protein and fibre components. The useful proteins form complexes with carbohydrate and thereby making them less digestible. Temperature is one of the essential factors affecting silage colour. The lower the temperature the better the silage, the less the colour change. If the temperature obtained for the present silages was above $30^{\circ} \mathrm{C}$ the grass silage would have become dark yellow or brown due to caramelization of sugars in the forage (McDonald et al., 1995). However the temperature $\left(20^{\circ} \mathrm{C}\right)$ obtained in this study indicate well-made silage. The texture of the silages was firm which was expected to the best texture of good silage (Kung and Shaver, 2002). Slimy texture or mould or fungi growth indicates spoilage in the silage.

The $\mathrm{pH}$ value of the silages was within the range of 3.55.5 classified to be $\mathrm{pH}$ for good silage (Menesses et al., 2007). Generally $\mathrm{pH}$ is one of the simplest and quickest ways of evaluating silage quality. However, $\mathrm{pH}$ may be influenced by the moisture content and the buffering capacity of the original materials. Silage that has been properly fermented will have a much lower $\mathrm{pH}$ (be more acidic) than the original forage. Kung and Shaver (2002) in their interpretation of silage analyses stated that a good quality grass and legume silage-pH values in the tropics ranges between 4.3 and 4.7. The $\mathrm{pH}$ value of 4.3 obtained in this study was in agreement with $4.2-5.0$ reported by Babayemi (2009) and 4.3-4.7 by Kung and Shaver (2002) but lower than 4.5-5.5 reported by Meneses et al. (2007).

Ensiled re-growths of vetiver grass without cassava peels exhibit poor silage characteristics possessing pungent smell with mouldy growth. This indicates that vetiver being a tropical grass is low in water soluble carbohydrate. Woolford (1984) reported that tropical grasses and legumes are not natural ensilage material, because they have a low content of water soluble carbohydrates which are essential to successful ensilage this leads to them having a higher buffering capacity and leaves their proteins susceptible to proteolysis. This is in agreement with the suggestion for more water soluble carbohydrate in silage material for good fermentation (McDonald et al., 1995).

Chemical composition: Chemical composition of ensiled and unensiled 4, 6 and 8-week re-growths of vetiver grass is shown in Table 2. The dry matter ranged from $(29.95 \%)$ in 4 -wk ensiled to $(38.92 \%)$ in 8 -week unensiled. Crude protein from $(4.93 \%)$ in 8 -week ensiled to $(8.38 \%)$ in 4 week unensiled, ether extract ranged from $6.66-8.96 \%$ among the treatments while ash contents varied from $6.53-9.82 \%$. NDF ranged from (40.81\%) from 4week ensiled to $(68.76 \%)$ in 8 week unensiled. ADF ranged from $(22.75 \%)$ from 4 week ensiled to $(38.75 \%)$ in 8-week unensiled. It was observed that the DM of ensiled re-growths of vetiver were lower than the unensiled, this is consistent with the report of Babayemi (2009) who reported dry matter loss in silage. There was a decrease in CP contents of ensiled compared to unensiled, this is similar to the report of Idris et al. (1999), that corn stover reduced to 8.2\% CP from 9.6\% CP after ensiling. Babayemi (2009) and McDonald et al. (1995) also reported decrease in $\mathrm{CP}$ after ensiling. The CP contents of ensiled and unensiled 4-week are within the critical value of $7.0 \%$ or $70 \mathrm{~g} / \mathrm{kg}$ recommended for small ruminants (NRC, 1981) but lower than minimum protein requirement of $10-12 \%$ recommended by ARC (1984) for ruminants. The objective of silage making is not to alter chemical composition but to make forage available at all times.

Coefficient of preference: Presented in Table 3 is the forage acceptability of the ensiled grasses by WAD Goats. The forage preference on cafeteria basis revealed that 4 week vetiver grass ensiled with cassava peels was consumed most $(1.99 \mathrm{KgDM} /$ day $)$. On the basis of the quantity consumed the animal preference for 4-week ensiled with cassava peels was higher than the rest, with CoP above unity (3.90) while the rest had CoP below unity indicating that they were poorly accepted by the animals. The CoP varied 0.14-3.90. The 4-week silage had the highest CoP and was preferred while the rest were poorly accepted, the ensiled $100 \%$ re-growths without cassava peels and fresh unensiled were not accepted at all. There are number of factors that may influence acceptability of a forage or feed by small ruminants: plant physical structure and chemical composition are the most important factors that influence preference (Babayemi, 2009 and Van Soest, 1994). Unensiled vetiver grass at 4,6 and 8-week of regrowths were rejected by the experimental animals contrary to the reports of Aderinola et al. (2008), Nguyen

Table 2: chemical composition of ensiled and unensiled 4, 6 and 8-week re-growths of vetiver grass

\begin{tabular}{lllllllllll}
\hline Parameters & $\mathrm{A}$ & $\mathrm{B}$ & $\mathrm{C}$ & $\mathrm{D}$ & $\mathrm{E}$ & $\mathrm{F}$ & $\mathrm{G}$ & $\mathrm{H}$ & $\mathrm{I}$ \\
\hline Dry matter & $31.09^{\mathrm{c}}$ & $33.72^{\mathrm{b}}$ & $38.92^{\mathrm{a}}$ & $29.95^{\mathrm{d}}$ & $32.67^{\mathrm{c}}$ & $35.98^{\mathrm{ab}}$ & $29.95^{\mathrm{d}}$ & $32.69^{\mathrm{c}}$ & $36.23^{\mathrm{ab}}$ & SEM \\
Crude protein & $8.38^{\mathrm{a}}$ & $7.10^{\mathrm{b}}$ & $5.40^{\mathrm{c}}$ & $7.75^{\mathrm{ab}}$ & $6.56^{\mathrm{bc}}$ & $4.93^{\mathrm{c}}$ & $7.84^{\mathrm{ab}}$ & $6.79^{\mathrm{bc}}$ & $5.21^{\mathrm{c}}$ & 0.49 \\
Ether-extract & $6.66^{\mathrm{c}}$ & $7.02^{\mathrm{b}}$ & $7.87^{\mathrm{b}}$ & $9.42^{\mathrm{a}}$ & $8.76^{\mathrm{ab}}$ & $8.96^{\mathrm{ab}}$ & $6.67^{\mathrm{c}}$ & $7.52^{\mathrm{bc}}$ & $7.87^{\mathrm{b}}$ & 0.31 \\
Ash & $8.48^{\mathrm{a}}$ & $7.54^{\mathrm{b}}$ & $6.53^{\mathrm{c}}$ & $9.82^{\mathrm{a}}$ & $8.98^{\mathrm{a}}$ & $7.62^{\mathrm{b}}$ & $8.43^{\mathrm{a}}$ & $7.54^{\mathrm{b}}$ & $6.52^{\mathrm{c}}$ & 0.24 \\
NDF & $56.41^{\mathrm{c}}$ & $60.53^{\mathrm{b}}$ & $68.76^{\mathrm{a}}$ & $40.81^{\mathrm{d}}$ & $56.34^{\mathrm{c}}$ & $58.64^{\mathrm{bc}}$ & $56.23^{\mathrm{c}}$ & $58.01^{\mathrm{bc}}$ & $62.21^{\mathrm{b}}$ & 2.27 \\
ADF & $34.35^{\mathrm{c}}$ & $37.39^{\mathrm{b}}$ & $38.75^{\mathrm{a}}$ & $22.75^{\mathrm{d}}$ & $34.56^{\mathrm{c}}$ & $36.34^{\mathrm{bc}}$ & $33.32^{\mathrm{c}}$ & $36.34^{\mathrm{b}}$ & $37.42^{\mathrm{a}}$ & 0.47 \\
\hline
\end{tabular}

SEM = standard error of means. ${ }^{a, b, c, c, d}$ means with different superscripts on the same row are significantly different $(P<0.05)$. $A=4$ wk unensiled, $B=6$ wk unesiled, $C=8$ wk unensiled, $D=4$ week ensiled with cassava peels, $E=6$ week ensiled with cassava peels, $F=8$ week ensiled with cassava peels, $\mathrm{G}=$ Ensiled 100\% 4wk, $\mathrm{H}=$ Ensiled 100\% 6wk, I = Ensiled 100\% 8wk 
Pak. J. Nutr., 12 (6): 529-533, 2013

Table 3: Acceptability of Vetiver grass by WAD goats

\begin{tabular}{lcl}
\hline Parameters & MDC (kg/DM) & CoP \\
\hline Unensiled 4week & 0.13 & 0.25 \\
Unensiled 6week & 0.09 & 0.18 \\
Unensiled 8week & 0.07 & 0.14 \\
$60 \% 4 \mathrm{wk}+40 \% \mathrm{cpl}$ & 1.99 & 3.90 \\
$60 \% 6 \mathrm{wk}+40 \% \mathrm{cpl}$ & 0.40 & 0.78 \\
$60 \% 8 \mathrm{wk}+40 \mathrm{cpl}$ & 0.35 & 0.68 \\
$100 \% 4 \mathrm{wk}$ ensiled & 0.00 & 0.00 \\
$100 \% 6 \mathrm{wk}$ ensiled & 0.00 & 0.00 \\
$100 \% 8 \mathrm{wk}$ ensiled & 0.00 & 0.0 \\
\hline
\end{tabular}

MDC: Mean daily consumption, CoP: Coefficient of preference

et al. (2004) and Liu et al. (2003). Vetiver grass being a newly introduced forage grass to the animals, while low quantity of 6 and 8 week ensiled with cassava peels were consumed, Provenza and Balgh (1987) reported that inexperienced animals may completely reject or consume low quantity of a newly introduced forage for long periods compared to animals exposed to the forage early in life. The $100 \%$ ensiled grass without cassava peels were also rejected, this could be due to poor silage properties such as pungent smell which could repel the animals and mouldy growth which could poisonous (McDonald et al., 1985). It was observed that the inclusion of cassava peels enhanced the acceptability of the grass silage, because cassava peels has being regularly used to feed them. Acceptance of 4 week silage could be due to its low fibre content and it is less coarse. Hence, 4 weeks vetiver grass and cassava peels silage was selected for consequent experiments. The 4-week $100 \%$ ensiled without cassava peels that should serve as control was discarded because of its poor silage characteristics and rejection by the animals.

Conclusion: Results showed that silage characteristics in terms of colour, aroma, texture, $\mathrm{pH}$ and temperature were similar among the silage and were within the acceptable properties of well-made silage. 100\% ensiled re-growths of vetiver grass without cassava peels exhibit poor silage characteristics and were rejected by the experimental animals. Unensiled regrowths of vetiver grass were poorly accepted, while ensiling with cassava peels enhanced the acceptability by WAD goats.

\section{REFERENCES}

AOAC, 1995. The official methods of analysis. Association of official analytical chemist, 16th Edn., washinton D.C., pp: 69-88.

Aderinola, O.A., J.A. Akinlade, T.A. Rafiu and T. Fajinmi, 2008. Feed intake, digestibility and nitrogen balance of west African dwarf sheep and goat fed Vetiveria nigritana grass. Proceedings of 33rd annual conference of Nigerian society for animal production (2008), OOU Ayetoro, pp: 579-582.
ARC, 1984. The nutrient Requirements of Ruminant Livestock. Supplement no 1. Commonwealth agricultural bureaux, Slough, UK.

Babayemi, O.J. and J.A. Igbekoyi, 2008. In Eric Tielkes (Eds.), Competition for a resource in a changing world: New drive for rural development. Conference of the international research on food security, Natural resources management and rural development, tropentag, 7-9th October 2008.

Babayemi, O.J., 2009. Silage quality, dry matter intake and digestibility by African dwarf Sheep of Guinea grass (Panicum maximum $\mathrm{cv}$ ntchisi) harvested at 4 and 12 week regrowths. Afr. J. Biotechnol., 8: 3988-3989.

Babayemi, O.J., M.A. Bamikole and A.B. Omojola, 2006. Evaluation of the nutritive value and free choice intake of two aquatic weed (Neophrolepis biserrata and spirodelaplyrhiza) by west African dwarf goats. Trop. Subtropical Agro Ecosys., 6: 15-22.

Bamikole, M.A., U.J. Ikhatua, M.T. Ajulo and A.C. Osuji, 2004. Feed utillisation potential of west African dwarf goats fed different proportions of Ficus thonningii and Panicum maximum. Proceedings of the 29th Annual conference of Nigeria society of animal production, Vol., 29, pp: $336-340$.

Bolsen, K.K., G. Ashbell and Z.G. Weinberg, 1996. Silage fermentation and sillage additives. Rev. Asian-Aust. J. Anim. Sci., 9: 483-493.

Duncan, D.B., 1955. Multiple range and multiple F-test. Biometics, 11: 1-42.

Idris, A.B., A.M. Yusuf and A. Shariff, 1999. Sweet corn stover silage production. Proc. FAO e-Conf. on Trop. Silage. FAO Plant Production and Prrotection paper 161. Rome107-108.

Karbo, N., P. Barnes and H. Rudat, 1993. An evaluation of browse forage preference by sheep and goat in northern Savanna zone Ghana. In : J. Ndikumanaan, P. DeLeeuw (Eds). Proceeding of the 2nd African Feed Resource Network (AFRNETA) on sustainable feed production and utilisation smallholder of livestock enterprises in sub-saharan African. Harare, Zimbabwe.

Kung, L. and R. Shaver, 2002. Interpretation and use of silage fermentation analyses reports. Dept. of animal and food science, University of Delaware Newark, DE 19717.

Liu, P., C. Zheng, Y. Lin, F. Luo, X. Lu and D. Yu, 2003. Study on digestibility of nutrient content of vetiver grass (China Vetiver Workshop).

Mannatje, L.'t'., 1999. Introduction to the conference on silage making in the tropics in Mannetje (eds) silage making in the tropics with particular emphasis on small holders FAO plant production and protection. Paper, 161. 
Menesses, M.D., J. Megias, A. Madrid, F. Martinez-Teruel, J. Hemandez and J. Oliva, 2007. Evaluation of the phytosanitary, fermentative and nutritive characteristics of the silage made from crude artichoke (Cynarascolymus L.) by-products feeding for ruminants. Small Ruminant Res., 70: 292-296.

McDonald, P., R.A. Edward and J.F.D. Greenhalgh, 1995. Animal nutrition, 5th Edn., Longman Scientific and Technical, England.

Muck, R.E., 1996. Silage inoculation: In Inoculation of Silage and Its Effect on Silage quality, US, Dairy Forage Research Center, Int. Conf. With Dairy and Forage Industries, pp: 43-51.

Nguyen, V.H., T.H.N. Nguyen, A.Q. VO and V.N. Pham, 2004. Digestibility of Nutrient Content of Vetiver grass by Goats Raised in the Mekong Delta, Vietnam. www. Vetiver.org/proceeding/nhanpdf.

NRC, 1981. Nutrients requirement for goat. Angora dairy and meat goat in temperate and tropical continent. National research council, national academy of science press, Washinton DC.

Provenza, F.P. and D.F. Balgh, 1987. Diet learning by domesticruminants: theory, evidence and practical implication. Applied Anim. Behav. Sci., 18: 112-232.
Oduguwa, B.O., A.O. Jolaosho and M.T. Ayankoso, 2007. Effect of ensiled on physical properties, chemical composition and mineral contents of guinea grass and cassava tops silage. Nig. J. Anim. Prod., 34: 100-106.

SAS, 2002. User guide of statistical analysis institute inccary .NC.

Troung, P.V. and D. Baker, 1998. Vetiver grass system for environmental protection logy. Bulletin No.1998/1PVV/ORDPB, Bangkok, Thailand.

Van Soest, P.J., J.B. Robertson and B.A. Lewis, 1991. Methods for dietary fibre, neutral detergent fiber and non-starch polysaccharides in relation to animal nutrition. J. Dairy Sci., 74: 3583-3597.

Woolford, M.K., 1984. The microbiology of Silage, chapter 2 In: Marcel Dekker Inc. New York, USA, pp: 23-59.

Oduguwa, B.O., A.O. Jolaosho and M.T. Ayankoso, 2007. Effect of ensiled on physical properties, chemical composition and mineral contents of guinea grass and cassava tops silage. Nig. J. Anim. Prod., 34: 100-106. 